\title{
O SUPREMO TRIBUNAL FEDERAL BRASILEIRO EM 2015. TENDÊNCIAS JURISPRUDENCIAIS
}

\author{
2015 Brazilian Supreme Court Case Law Tendencies
}

\author{
PAULO GUSTAVO GONET BRANCO' \\ Instituto Brasiliense de Direito Público \\ pgbranco@gmail.com
}

Cómo citar/Citation

Gonet Branco, P. G. (2016).

O Supremo Tribunal Federal brasileiro em 2015. Tendências jurisprudenciais. Anuario Iberoamericano de Justicia Constitucional, 20, 465-491. doi: http://dx.doi.org/10.18042/cepc/aijc.20.16

\section{SUMARIO}

I. O PROCESSO DE IMPEACHMENT DEFINIDO NO SUPREMO TRIBUNAL FEDERAL. II. IMPEACHMENT NOS ESTADOS-MEMBROS. III. PODE O PRESIDENTE DA REPÚBLICA SER OBJETO DE INQUÉRITO POLICIAL NO CURSO DO SEU MANDATO? IV. A DELAÇÃO PREMIADA EM SI É VÁLIDA? A CONDENAÇÃO PODE NELA SE BASEAR? V. PRESUNÇÃO DE INOCÊNCIA E INÍCIO DO CUMPRIMENTO DA SANÇÃO PENAL. VI. SITUAÇÃO PENITENCIÁRIA DESUMANA E DEVER DE AGIR DO ESTADO. VII. ESTADO DE COISAS INCONSTITUCIONAL E AUDIÊNCIA DE CUSTÓDIA. VIII. OS NÚMEROS DE 2015 DO CONTROLE POR VIA DE AÇÃO DIRETA DE INCONSTITUCIONALIDADE. IX. CONCURSOS PÚBLICOS - UM TEMA RECORRENTE NO STF. X. PLICAÇÃO DE PRINCÍPIOS REITORES DE UMA ADMINISTRAÇÃO DEMOCRÁTICA. XI. O STF E O DIREITO POLÍTICO. XII. LIBERDADE DE EXPRESSÃO, DIREITO A INFORMAÇÃO E PRIVACIDADE. XIII. DIREITOS SOCIAIS E IGUALDADE. XIV. FEDERAÇÃO. XV. CONCLUSÃO.

1 Doutor em Direito. Subprocurador-Geral da República com atuação perante o Supremo Tribunal Federal. Coordenador do Programa de Mestrado do Instituto Brasiliense de Direito Público (IDP). 
No ano de 2015, o Brasil vivenciou situações políticas, econômicas e sociais típicas de um quadro de crise aguda. A Presidente da República, reeleita no final do ano anterior, após renhida disputa eleitoral, experimentou um início turbulento do seu último mandato. $\mathrm{O}$ país se viu na contingência de enfrentar cenário internacional adverso no campo do comércio de commodities, inflação em disparada, controle fiscal deficiente do governo, desemprego atingindo alarmantes índices, juros altos e crescimento econômico apontando para percentuais negativos. Hesitações no cumprimento de promessas eleitorais não melhoraram o ânimo da população. Sobretudo escândalos de corrupção, atingindo personalidades do alto escalão da base governamental, geraram inédito e incontido mal-estar, levando milhôes de pessoas às ruas das principais cidades brasileiras, para protestar contra desmandos na gestão da coisa pública.

Os espaços públicos converteram-se em ambientes francamente hostis ao governo recém-inaugurado. Em diversos centros urbanos, o barulho de panelaços, produzidos às janelas dos edifícios residenciais, repenicava no mesmo instante em que pronunciamentos oficiais eram transmitidos em cadeia de rádio e televisão. As crises econômica e política se realimentavam em alvoroços de crescentes e atroadores ímpetos. A crise ética no domínio político se estampava em perturbadoras evidências de envolvimento em negociatas bilionárias de agentes públicos que estiveram em funções de mando no país na última década. Com pasmo foi-se percebendo que estava abalada a base financeira da maior empresa brasileira, e uma das maiores petrolíferas do mundo, a Petrobrás.

As investigações criminais promovidas pelo que ficou conhecido como «operação lava-a-jato» assombraram a cidadania, atingindo próceres do sistema econômico e político. As ruas foram-se tomando de apoiadores do processo de investigação, exigindo que as apurações se adensassem até que todos os envolvidos fossem expostos. O prestígio de partidos políticos importantes sofreu contínuo revés. Mais adiante no ano, foi divulgada a crítica deduzida no Tribunal de Contas da União a procedimentos adotados pelo governo no campo orçamentário, vistos por três renomados juristas, um deles fundador do próprio partido da Chefe do Executivo Federal, como caracterizadores de crime de responsabilidade por parte da Presidente da República. Os três levam, solenemente, a protocolo da Câmara dos Deputados petição requerendo o impeachment da Presidente. A essa altura, apoiadores do partido do governo reagiram e uma batalha verbal passou a se travar de modo ímpar nas redes sociais. Afinal, o pedido de impeachment foi admitido pela Câmara dos Deputados e admitido também no Senado Federal, ensejando o afastamento da Presidente da República do cargo, e abrindo a fase do julgamento no Senado Federal, que, em junho de 2016, ao tempo em que este artigo é escrito, ainda não se ultimou. 
Mesmo que o leitor estrangeiro não tenha acompanhado as etapas desse atordoante ano de 2015 vivido pelos brasileiros, não lhe custará demasiado conjecturar como foram agitados esses dias no país. Como não poderia deixar de ser, os desassossegos apresentavam suas facetas no âmbito do Direito, puxando à cena das notícias do quotidiano o Judiciário, em especial o Supremo Tribunal Federal. Algumas das decisões de maior impacto na sociedade do ano de 2015 surgem nesse ambiente singular da história política do Brasil.

\section{O PROCESSO DE IMPEACHMENT DEFINIDO NO SUPREMO TRIBUNAL FEDERAL}

Iniciado o processo de impeachment na Câmara dos Deputados, surgiram dúvidas sobre o rito a ser seguido. $\mathrm{O}$ diploma que disciplina a matéria, Lei no 1.079 , de 1950, foi editado na vigência de Constituição já não mais em vigor. A lei, porém, já havia sido aplicada na atual ordem constitucional, quando, em 1992, um outro Presidente da República foi impedido. À época, o Supremo Tribunal Federal também foi chamado a delinear o procedimento devido, o que auxiliou a Corte a, nas últimas sessões do Plenário do Tribunal de 2015, em 16 e 17 de dezembro, revisitar a questão na ADPF $378 \mathrm{MC}$.

Alguns aspectos interessantes, do ponto de vista formal, marcaram o julgamento. $\mathrm{O}$ voto do relator para o acórdão, Min. Roberto Barroso, observou que a ação buscava a "realização de uma filtragem constitucional da Lei $\mathrm{n}$. 1.079/1950, de modo a tornar claro e estreme de dúvida quais de suas normas se mantêm em vigor e quais foram revogadas, bem como a forma pela qual as remanescentes devem ser interpretadas». Haveria também de se suprir a omissão do legislador no tocante à observância de garantias constitucionais mais encarecidas na Constituição de 1988. O Tribunal respondeu a objeção de descabimento da ação, afirmando ser «viável manejar uma única ação direta, no caso, a ADPF, com cumulação dos pedidos de não recepção de norma anterior à Constituição, de declaração da inconstitucionalidade de norma posterior e de superação da omissão parcial inconstitucional». Sobre este último ponto, o Ministro se reportou à jurisprudência mais recente da Corte, que vem admitindo que os vazios legislativos infringentes de direitos constitucionais sejam preenchidos judicialmente. $\mathrm{O}$ argumento é de especial relevância para que se compreenda esse complexo tema do controle de constitucionalidade no país e merece ser reproduzido:

O STF já se manifestou expressamente pela viabilidade da produção de decisão aditiva que supra omissão legislativa parcial, estabelecendo um regramento provisório, com eficácia geral, para evitar que a omissão inconstitucional paralise a eficácia das 
normas constitucionais (cf. MI 670, 708 e 712, sobre o direito de greve dos servidores públicos). Além disso, a Lei n. 12.063/2009 (art. 12-F, $\$ 10$ ), ao prever expressamente a possibilidade de deferimento de cautelar em ADO [ação direta de inconstitucionalidade por omissão], determinou que tal cautelar poderá suspender a aplicação do ato normativo questionado (em caso de omissão parcial), os processos judiciais ou administrativos em curso ou, ainda, determinar qualquer "outra providência a ser fixada pelo Tribunal». Essa última norma indica a possibilidade de adoção de decisões aditivas pelo Supremo também em ADO.

Enfim, o Tribunal apontou que o «dramático quadro político e econômico» impunha uma palavra definitiva e global do STF, prevenindo que múltiplas questôes em diversos processos conduzissem a soluções "casuísticas e assistemáticas, em evidente prejuízo à segurança jurídica».

Por fim, o acórdão censurou atos do Presidente da Câmara, declarou insubsistentes dispositivos da lei de 1950 e supriu as omissões daí resultantes, para coordenar os princípios constitucionais envolvidos na polêmica.

O Supremo Tribunal assentou que o papel da Câmara dos Deputados deveria ser diferente daquele disposto na Lei $\mathrm{n}^{\circ} 1.079 / 50$, em face do novo desenho normativo traçado pelo constituinte de 1988 . Assim, não cabe à Câmara dos representantes do povo deliberar sobre o mérito da acusação, que pode ser deduzida por qualquer cidadão, mas, tão-somente, realizar «um juízo eminentemente político sobre os fatos narrados, que constitui condição para o prosseguimento da denúncia». Por isso mesmo, não se cobra o exercício de ampla defesa nessa fase. A defesa, aqui, deve ser deduzida, no prazo de dez sessões da Casa e dirigida a Comissão aberta para esse fim. A Comissão lavra, então, parecer, que será apreciado no Plenário. Para que haja a admissão do processo, a providência deve ser abonada por 3/5 dos membros da Câmara (342 de 513 Deputados Federais).

Admitida a denúncia, o Presidente da República não fica afastado do exercício do cargo. Este último evento é consequência de uma deliberação seguinte do Senado Federal, que aprecia parecer de Comissão instituída com a finalidade de examinar a questão. O Senado vota, nesse primeiro instante, se aceita ou recusa a denúncia vinda da Câmara dos Deputados. A decisão se dá por maioria simples, presentes 41 Senadores. Mesmo, portanto, que a Câmara dos Deputados haja admitido o pedido de impeachment, o Senado pode rejeitá-lo por maioria simples. Se for recebida a denúncia, porém, dá-se o afastamento do Presidente da República do seu cargo por até 180 dias. Vencido esse lapso sem deliberação final do Senado, o Presidente afastado retorna às suas funçôes, sem prejuízo da continuidade do processo.

Recebida a denúncia, ademais, franqueia-se ao Presidente afastado o direito à ampla defesa. Podem ser produzidas provas orais, escritas, perícias, 
enfim, o que for útil para a elucidação do que é arguido na peça acusatória. Neste instante, o julgamento já corre sob a presidência do Presidente do Supremo Tribunal Federal, que pode concordar com produção de provas que haja sido recusada no âmbito da Comissão Especial formada no Senado para dar curso ao processo.

O STF estabeleceu que o interrogatório do Presidente da República, entendido como instrumento de autodefesa sua, deve ser o derradeiro ato da instrução processual.

O processo culmina com a votação sobre a procedência ou improcedência da denúncia. O juízo condenatório exige o voto de $3 / 5$ dos Senadores. Se absolvido, o Presidente da República retorna às suas funçōes, podendo sofrer outros pedidos de impedimento. Condenado, perde o cargo e se torna inelegível por 8 anos. Nesse caso, o Vice-Presidente, que estava na interinidade da Chefia do Estado, torna-se Presidente da República pelo restante do mandato que faltava a ser cumprido. Não há, portanto, convocação de eleições extemporâneas.

A índole política do processo é inegável, o procedimento está delimitado, contudo, por regras asseguradoras da ampla defesa do acusado e do fair trial. As amplas maiorias requeridas para o andamento do processo e para a condenação atuam como elementos de contenção de processos iníquos e mal-avisados. O impeachment, assim, previsto expressamente na Constituição, que se define como democrática, não se reduz a mecanismo deturpador do Estado Democrático de Direito instaurado em 1988.

\section{IMPEACHMENT NOS ESTADOS-MEMBROS}

Num Estado Federal, é de se esperar que, da mesma forma que no âmbito da União, o Estado-membro também possa prever o afastamento do seu Chefe do Executivo, por crime de responsabilidade. A questão a ser enfrentada é se os Estados-membros devem seguir o procedimento do impeachment do Presidente da República, i.é, se o modelo federal a eles se impõe obrigatoriamente. Em ações diretas de inconstitucionalidade contra normas de três Estados da Federação, o STF estabeleceu em que medida o procedimento deve ser reproduzido (ADI 4791/PR, ADI 4800/RO e ADI 4792/ES, julgadas em 12.2.2015.

Nos precedentes, o STF assentou que é da competência legislativa privativa da União legislar sobre a definição de crime de responsabilidade e o seu processamento. Foi reafirmada a mesma inteligência expressa na Súmula 722 da jurisprudência da Corte. A Lei no 1.079/1950, então, compreendidos os seus termos de acordo com a leitura modernizante do Supremo Tribunal, deve ser observada também nos Estados-membros, não lhes sendo dado, nem 
mesmo por meio das suas Constituições, dispor sobre fatos típicos ou sobre o processo de modo diferente do determinado na lei federal. Diante disso, foi considerado inconstitucional que o constituinte estadual estabelecesse que o processo de impeachment do Governador haveria de correr no âmbito da Assembleia Legislativa, já que a lei de 1950 indica o Tribunal de Justiça como lugar do seu desenvolvimento. $\mathrm{O}$ princípio da simetria, aqui, não se aplica. Por outro lado, as normas das Constituições estaduais que demandam prévia autorização da Assembleia Legislativa, por 2/3 dos seus membros, para o processo foram tidas como válidas, espelhando, agora devidamente, a solução da Constituição Federal. Foi dito que: «A exigência de autorização prévia por 2/3 dos membros da Câmara dos Deputados para a instauração de processo contra o presidente não se vincula a nenhuma prerrogativa típica e exclusiva inerente às atribuiçôes do presidente da República, no exercício do cargo de chefe de Estado».

\section{PODE O PRESIDENTE DA REPÚBLICA SER OBJETO DE INQUÉRITO POLICIAL NO CURSO DO SEU MANDATO?}

Referências feitas à Presidente da República em procedimentos criminais durante a operação lava-a-jato levaram partidos de oposição a insistir em que fosse aberto inquérito policial para investigá-la. O Procurador-Geral da República não assentiu no pedido. Os partidos, então, peticionaram ao Supremo Tribunal Federal, pedindo que a providência fosse adotada, apresentando-se como assistentes da acusação. $\mathrm{O}$ relator, em decisão monocrática nessa Pet 5569, em 15/05/2015, anotou —e nesse ponto o interesse maior da deliberação — que, embora a ação penal contra o Presidente da República por fato alheio ao desempenho do mandato não possa ser instaurada no decorrer deste, não haveria igual restrição para o início de procedimentos investigatórios, antecedentes da ação penal. Salientou, porém, ser irrecusável o pedido do Procurador-Geral da República de arquivamento de peças de comunicação de crime. Por isso, "não havendo acusação alguma formalmente apresentada em relação à Presidente da República, não há como, logicamente, admitir a presença de assistente de acusação.»

\section{A DELAÇÃO PREMIADA EM SI É VÁLIDA? A CONDENAÇÃO PODE NELA SE BASEAR?}

A operação lava-a-jato, que desvendou horripilantes vínculos de corrupção entre agentes políticos e potentados da economia, viabilizou-se por força 
de delações premiadas. $\mathrm{Na}$ medida em que servidores de escalão médio eram flagrados em peripécias malsãs, abria-se-lhes a possibilidade de redução de pena ou de cumprimento da condenação vindoura em condições mais amenas, se revelassem pormenores desconhecidos das engrenagens da corrupção em que se inseriam, apontando figuras mais importantes à frente do esquema criminoso. A colaboração, ou delação, premiada é procedimento regulado em lei (Lei $\left.n^{\circ} 12.850 / 2013\right)$, sendo negociada entre o Ministério Público e o investigado, dependendo, para ser eficaz, de homologação judicial. Ainda assim, com o crescente número de delações, iniciou-se movimento de resistência ao procedimento, em especial quando realizado por pessoas que já se encontravam em prisão provisória.

$\mathrm{Na}$ Pet. 5.700, a decisão monocrática, de 22.9.2015, do Ministro relator Celso de Mello, situou a denunciação (ou colaboração) premiada no contexto da sua acolhida pela mais recente lei a respeito, editada em 2013. Sem ingressar nas considerações de ordem ética que podem ser suscitadas, o relator admitiu a validade do mecanismo de colaboração do acusado com a Justiça, enfatizando que a experiência do direito comparado permitiu o desenvolvimento mais seguro do instituto entre nós. Referiu-se, neste ponto, ao caso Enzo Tortora, ocorrido na década de 1980, em que um inocente, injustamente delatado por membros da Nuova Camorra, sofrera as consequências de sombrio erro judicial. Observou que a colaboração premiada foi normatizada no Brasil em harmonia com documentos internacionais como a Convenção de Palermo e a Convenção de Mérida. Mas, ressaltou que o depoimento do colaborador premiado, por si só, é insuficiente para embasar uma condenação penal, mesmo havendo mais de um depoimento de pessoas nessa qualidade. Se, entretanto, outro testemunho, de alguém que não seja agente colaborador, vier a se somar, o que foi revelado pelo delator ganha poder de persuasão legítimo para o magistrado. A decisão se reportou a jurisprudência do STF há muito estabelecida, no sentido de que «se, de um lado, a delação, de forma isolada, não respalda condenação, de outro, serve ao convencimento quando consentânea com as demais provas coligidas» (HC 75.226/MS, DJ 19.9.1997). Registrou que a imputação falsa e a mentira sobre fatos são punidas como infração penal. Reprovou, por derradeiro, a hipótese de a prisão servir meramente como estímulo para a colaboração premiada.

\section{PRESUNÇÃO DE INOCÊNCIA E INÍCIO DO CUMPRIMENTO DA SANÇÃO PENAL}

Em decisão que provocou acesos debates acadêmicos, o STF recuou da inteligência formada em 2009 (HC 84.078), no sentido de que somente após 
o trânsito em julgado da condenação penal, o réu poderia ser recolhido à penitenciária.

Até 2009, o esgotamento das instâncias ordinárias era suficiente para conduzir à prisão o condenado por crime, ainda que lhe estivessem ainda abertas as instâncias especial do Superior Tribunal de Justiça e extraordinária do Supremo Tribunal Federal. Isso porque, nesses altos Tribunais, apenas questóes de direito - e nunca de fato - podem ser suscitadas. Além disso, ao tempo, esses recursos não suspendiam, automaticamente, a eficácia decisão tomada na instância ordinária.

A virada da jurisprudência de 2009 deu-se para prestigiar uma compreensão mais extensiva da garantia da presunção de inocência, que, na Constituição brasileira, aparece vertida no seu art. $5^{\circ}$, LVII, com estes termos: «Ninguém será considerado culpado até o trânsito em julgado de sentença penal condenatória».

O raciocínio que se impôs em 2009 foi o de que não se poderia aprisionar, senão pelos motivos próprios de medida cautelar penal, quem a Constituição não admitia que fosse considerado definitivamente culpado.

Ao longo dos anos que se sucederam, a sociedade conviveu com episódios de mal-estar decorrentes dessa interpretação. Os condenados que contratavam advogados astutos protelavam por vários anos o momento do cumprimento de pena, valendo-se dos recursos especial e extraordinário, de agravos de instrumento, agravos regimentais e embargos de declaração, que se sucediam em número desafiador das fronteiras da irrisão. $\mathrm{Na}$ academia, nos meios jornalísticos e no Ministério Público ergueram-se vozes contra a sensação de impunidade que esse quadro tracejava. A repulsa pelos crimes que se foram desvendando nas tantas etapas da operação lava-a-jato contribuiu para a insatisfação com o modelo de inteligência fixado na década passada. Em 15 de dezembro de 2015, teve início o julgamento do HC 126.292, com a remessa do feito para o Plenário do Tribunal, e, em 17.2.2016, assentou-se que «a execução provisória de acórdão penal condenatório proferido em grau de apelação, ainda que sujeito a recurso especial ou extraordinário, não compromete o princípio constitucional da presunção de inocência afirmado pelo artigo 5º, inciso LVII da Constituição Federal.»

O Tribunal, por maioria de 7 a 4 Ministros, entendeu que o princípio da presunção de inocência pode ser conformado de variados modos, tendo em vista a necessidade de efetividade da Justiça Penal, evitando-se situações ensejadoras de prescrição e de impunidade, propiciadas por recursos eminentemente protelatórios. Voltou-se a adotar o argumento, corrente antes de 2009, de que a condenação nas instâncias ordinárias «imprime acentuado juízo de consistência da acusação, o que autoriza, a partir daí, a prisão como consequência natural da condenação». Ouviu-se que, «em país algum do mundo, 
depois de observado o duplo grau de jurisdição, a execução de uma condenação fica suspensa, aguardando referendo da Suprema Corte». Tornou-se a argumentar que o recurso de natureza extraordinária, como é o dirigido nesses casos ao Supremo Tribunal Federal, «não têm por finalidade específica examinar a justiça ou a injustiça de sentenças em casos concretos. Destinam-se, precipuamente, à preservação da higidez do sistema normativo». Argumentou-se que o recurso extraordinário somente pode ser conhecido se houver uma questão constitucional de repercussão geral, que transcenda o interesse subjetivo da parte; por isso, não haveria sentido em adiar a execução da pena para além do juízo ordinário que o processo criminal comporta.

\section{SITUAÇÃO PENITENCIÁRIA DESUMANA E DEVER DE AGIR DO ESTADO}

Caso de grande repercussão foi julgado no Plenário da Corte em 13 de agosto de 2015. Cuidava-se de recurso extraordinário contra acórdão de Tribunal de Justiça que, invocando o princípio da separação dos poderes e os limites da reserva do possível, frustrara pleito do Ministério Público, que havia sido acolhido na primeira instância, para que o Poder Público executasse, sem demora, obras emergenciais em certo lugar de cumprimento de pena.

$\mathrm{O}$ acórdão do STF situou as condiçôes do lugar no contexto do que afirmou ser, notoriamente, o «dantesco» quadro dos presídios no país. Valendo-se de relatos constantes dos autos, entendeu que a situação do "Albergue Estadual é efetivamente atentatória à integridade física e moral de seus detentos». Dentre tantos problemas do imóvel, anotou que os detentos «estão permanentemente expostos a risco de morte em razão das péssimas condições da fiação elétrica do citado Albergue, havendo notícia, inclusive, de que um dos presos perdeu a vida por eletrocussão». Acrescentou que o estado de "caos institucional, à toda evidência, compromete a efetividade do sistema prisional como instrumento de reabilitação social dos detentos, a começar pela carência crônica de vagas, que faz com que os estabelecimentos carcerários sejam verdadeiros «depósitos» de pessoas». Finalmente, invocou, para justificar a intervenção judicial, o princípio da dignidade da pessoa humana, indispensável para que «seu conteúdo mínimo seja assegurado aos jurisdicionados em qualquer situação em que estes se encontrem». Afastou de antemão a crítica de estar atuando no campo das políticas públicas, porquanto disso não se poderia cogitar quando a Administração não dispõe de escolha sobre agir. Quanto ao argumento da falta de recursos, valeu-se de pesquisa no portal do Ministério da Justiça para desmentir a perspectiva, anotando haver a disponibilidade de mais de dois bilhôes de reais para obras no setor penitenciário, quantia que, 
sistematicamente, deixa de ser aplicada para a finalidade a não ser por uma parca fração. Por fim, o Tribunal formulou esta máxima de julgamento, que deve ser observada por todos os órgãos do Judiciário:

É lícito ao Judiciário impor à Administração Pública obrigação de fazer, consistente na promoção de medidas ou na execução de obras emergenciais em estabelecimentos prisionais. Supremacia da dignidade da pessoa humana que legitima a intervenção judicial. Impossibilidade de opor-se o argumento da reserva do possível ou princípio da separação dos poderes.

\section{ESTADO DE COISAS INCONSTITUCIONAL E AUDIÊNCIA DE CUSTÓDIA}

Num instrumento de controle de constitucionalidade abstrato, na ADPF $347 \mathrm{MC}$, o Supremo retornou, poucos dias depois, em 9.9.2015, ao assunto da inadmissível precariedade do sistema prisional brasileiro. Desta vez, o tema foi analisado com o empréstimo do conceito desenvolvido na Colômbia, durante a década de 1990, e também a propósito de problemas carcerários, do estado de coisas inconstitucional.

$\mathrm{O}$ quadro caótico das penitenciárias já havia sido pintado no julgado anterior e foi reiterado com duras palavras. Viu-se no excesso de prisões e no número deficitário de vagas para condenados e presos provisórios o ponto inicial do problema a ser enfrentado. O Ministro relator expôs estes dados:

Segundo as investigaçoes realizadas, a população carcerária, maioria de pobres e negros, alcançava, em maio de 2014, 711.463 presos, incluídos 147.397 em regime domiciliar, para 357.219 vagas disponíveis. Sem levar em conta o número de presos em domicílio, o déficit é de 206.307, subindo para 354.244, se computado. A deficiência de vagas poderia ser muito pior se não fossem os 373.991 mandados de prisão sem cumprimento. Considerando o número total, até mesmo com as prisões domiciliares, o Brasil possui a terceira maior população carcerária do mundo, depois dos Estados Unidos e da China.

A maior parte desses detentos está sujeita às seguintes condições: superlotação dos presídios, torturas, homicídios, violência sexual, celas imundas e insalubres, proliferação de doenças infectocontagiosas, comida imprestável, falta de água potável, de produtos higiênicos básicos, de acesso à assistência judiciária, à educação, à saúde e ao trabalho, bem como amplo domínio dos cárceres por organizaçóes criminosas, insuficiência do controle quanto ao cumprimento das penas, discriminação social, racial, de gênero e de orientação sexual. 
Delimitou, então, o objeto da ação, descrito dessa forma:

Esta arguição envolve a problemática do dever de o Poder Público realizar melhorias em presídios ou construir novos com a finalidade de reduzir o déficit de vagas prisionais. Vai além: versa a interpretação e a aplicação das leis penais e processuais de modo a minimizar a crise carcerária, implantar a forma eficiente de utilização dos recursos orçamentários que compõem o Fundo Penitenciário Nacional - FUNPEN e o dever de elaboração, pela União, estados e Distrito Federal, de planos de ação voltados a racionalizar o sistema prisional e acabar com a violação de direitos fundamentais dos presos sujeitos às condições de superlotação carcerária, acomodaçôes insalubres e falta de acesso a direitos básicos, como saúde, educação, alimentação saudável, trabalho, assistência jurídica, indispensáveis a uma vida minimamente digna e segura.

Proclamou configurado o estado de coisas inconstitucional, «ante a ocorrência de violação maciça de direitos fundamentais dos presos, resultante de ações e omissões dos Poderes Públicos da União, dos Estados e do Distrito Federal, considerado o quadro de superlotação carcerária e das condições degradantes das prisões do país». Recordou que os pressupostos dessa enfermidade constitucional, descritos em precedentes da Corte Constitucional Colombiana, estavam todos presentes: «situação de violação generalizada de direitos fundamentais; inércia ou incapacidade reiterada e persistente das autoridades públicas em modificar a situação; a superação das transgressões exigir a atuação não apenas de um órgão, e sim de uma pluralidade de autoridades».

O Tribunal apontou como direitos fundamentais hostilizados por essa situação de omissão a "dignidade da pessoa humana (artigo 1o, inciso III); a proibição de tortura e tratamento desumano ou degradante de seres humanos (artigo 5o, inciso III); a vedação da aplicação de penas cruéis (artigo 5o, inciso XLVII, alínea «e»); o dever estatal de viabilizar o cumprimento da pena em estabelecimentos distintos, de acordo com a natureza do delito, a idade e sexo do apenado (artigo 5o, inciso XLVIII); a segurança dos presos à integridade física e moral (artigo 5o, inciso XLIX); e os direitos à saúde, educação, alimentação, trabalho, previdência e assistência social (artigo 6o) e à assistência judiciária (artigo 5o, inciso LXXIV)».

O diagnóstico foi o de que somente um novo padrão de comportamento dos Poderes Públicos no campo normativo, administrativo e judicial poderia contribuir eficazmente para superar o dramático problema. Em face do descaso político para com o assunto, e invocando a sua vocação de agente contramajoritário, o Tribunal afirmou ser o seu dever agir e impor ações:

Não se tem [aqui] tema "campeão de audiência", de agrado da opinião pública. Ao contrário, trata-se de pauta impopular, envolvendo direitos de um grupo de pessoas 
não simplesmente estigmatizado, e sim cuja dignidade humana é tida por muitos como perdida, ante o cometimento de crimes. Em que pese a atenção que este Tribunal deve ter em favor das reivindicações sociais majoritárias, não se pode esquecer da missão de defesa de minorias, do papel contramajoritário em reconhecer direitos daqueles que a sociedade repudia e os poderes políticos olvidam, ou fazem questão de ignorar.

Insistiu, em outra passagem, em que:

Apenas o Supremo revela-se capaz, ante a situação descrita, de superar os bloqueios políticos e institucionais que vêm impedindo o avanço de soluções, o que significa cumprir ao Tribunal o papel de retirar os demais Poderes da inércia, catalisar os debates e novas políticas públicas, coordenar as ações e monitorar os resultados. Isso é o que se aguarda deste Tribunal e não se pode exigir que se abstenha de intervir, em nome do princípio democrático, quando os canais políticos se apresentem obstruídos, sob pena de chegar-se a um somatório de inércias injustificadas.

A medida cautelar requerida na ação, foi deferida para impor aos juízes que realizassem audiências de custódia, em que tivessem contato com o preso, no prazo máximo de 24 horas do instante da detenção. O juiz, então, há de decidir se mantém a prisão ou se imediatamente a relaxa, não havendo motivo imperioso em contrário. $\mathrm{O}$ acórdão, na convicção de a implementação dessas audiências reduzirá o contingente de presos cautelarmente, enalteceu a economia de gastos a ser conquistada, estimando o custo médio de cada preso em dois mil reais mensais (aproximadamente, 520 euros).

Foi imposta também a liberação dos recursos destinados ao sistema carcerário, mantidos pelo Executivo no Fundo Penitenciário Nacional, que não vinham sendo postos à disposição das urgentes medidas de renovação dos presídios.

\section{OS NÚMEROS DE 2015 DO CONTROLE POR VIA DE AÇÃO DIRETA DE INCONSTITUCIONALIDADE}

Não obstante a atenção que os problemas políticos trouxeram para o STF, a Corte teve um ano produtivo em suas várias áreas de atuação. Foram julgadas, por exemplo, 69 ações diretas de inconstitucionalidade, com juízo de procedência em 49 delas, sendo que, com relação às 20 restantes, em 4 casos não houve pronunciamento de mérito, por falta de pressuposto para tanto. Ainda assim, o número de julgamentos não é suficiente para reduzir o vasto estoque de demandas represadas por não encontrarem espaço na pauta do ano. As ações diretas de inconstitucionalidade não são levadas a Plenário por 
ordem de entrada no Tribunal, mas por escolha livre do Presidente da Corte. Como há variados assuntos nas mais de mil e seiscentas ações diretas propostas, é possível realizar pautas com temas afins e efetuar uma filtragem dos casos segundo a sua relevância para o momento. Em alguma medida, isso se verifica na prática do Tribunal, embora um estudo mais atento do que ocorre e da sua relevância para o papel da Corte Constitucional no processo político ainda esteja por despertar estudos acadêmicos.

Em 2015, claramente buscou-se atualizar a pauta das ADIs, tanto assim que dos processos dessa sorte julgados, 17 deram entrada no Tribunal ainda nos anos 1990. Outras 13 ações foram ajuizadas entre 2000 e 2005. Com relação à data da edição dos atos normativos impugnados, 48 dos 68 tinham sido publicados há mais de 15 anos $^{2}$.

As ações diretas se voltaram predominantemente contra atos normativos estaduais - apenas 14 dos atos impugnados proviam da União. Na maior parte das vezes, o vício que as afetou era de ordem formal, por desrespeito a reserva de iniciativa para apresentar o projeto de lei. Interessante notar que foram os Governadores os legitimados para agir que mais propuseram as ações julgadas. Propuseram 29 açôes, e em 22 lograram êxito. O Procurador-Geral da República foi o segundo legitimado pelo art. 103 da Constituição que mais vezes apareceu como autor nos casos apreciados no ano de 2015. Dez açóes foram por ele assinadas, sendo que 8 foram julgadas procedentes.

Os temas administrativos, especialmente relativos ao funcionalismo público, dominaram as querelas deduzidas em ação direta. Foram fulminadas, por exemplo, normas que criavam pensões especiais para agentes políticos.

Um tipo de pensão estabelecido na Capital da República também foi criticado. A Câmara Legislativa do Distrito Federal concebeu uma pensão especial a cônjuge de quem quer que houvesse sido vítima de crime qualificado como hediondo na unidade da Federação desde a inauguração de Brasília, em 1960 (ADI 1358, julgada em 4.2.2015).

No caso, o STF assinalou que a lei do Distrito Federal não se referia a hipótese de responsabilidade civil do Estado objetiva, prevista no art. $37, \$ 6^{\circ}$, da Constituição. Afirmou que, ainda assim, a pensão poderia ser criada, se assumisse natureza de assistência social. Ocorre que tampouco essa índole pôde ser identificada no benefício, uma vez que a lei não pressupunha a necessidade econômica do cônjuge supérstite, ao passo que o art. 203 da Constituição preceitua que «a assistência social será prestada a quem dela necessitar, independentemente de contribuição à seguridade social».

2 A propósito, o Anuário da Justiça Brasil 2016, editado pelo Consultor Jurídico e pela FGAAP. 
É interessante notar que o STF, valeu-se também da técnica da declaração de inconstitucionalidade por arrastamento no precedente. Uma vez que a própria pensão especial foi considerada inválida, os demais artigos da lei, que apontavam as parcelas dos recursos públicos que seriam destinadas a cobrir os custos, ficaram desprovidos de "sentido normativo autônomo"; por isso, a eles se estendeu a nulidade proclamada.

\section{CONCURSOS PÚBLICOS - UM TEMA RECORRENTE NO STF}

O leitor que haja acaso acompanhado as últimas resenhas da jurisprudência do Supremo Tribunal do Brasil, talvez venha a se dar conta das reiteradas vezes em que a Corte é chamada a fiscalizar normas e a definir direitos em torno do assunto do concurso público.

A Constituição de 1988, visando a prestigiar o princípio republicano, o da eficiência da Administração, o da igualdade e o da moralidade, dispõe que cargos de provimento efetivo, componentes de carreiras na burocracia estatal, somente podem ser providos por quem for aprovado em concurso público. As exceções são temporárias e emergenciais. A jurisprudência do STF sempre timbrou por conferir máxima eficácia a essa direção constitucional, combatendo a criatividade das medidas tomadas pelos poderes políticos para escapar à determinação do constituinte. No ano de 2015, nada menos de que 10 ações diretas foram julgadas a respeito desse problema. Para mero exemplo, cabe citar a ADI 3415, julgada em 24 de setembro, tendo por objeto lei que equiparava cargos distintos no âmbito da polícia civil de certo Estado-membro, transformando, em seguida, os cargos de uma das antigas carreiras em cargos da outra, de mais consistente prestígio. O Tribunal assim identificou o vício:

A forma pela qual foi conduzido o rearranjo administrativo revela que houve, de fato, burla ao postulado do concurso público, mediante o favorecimento de agentes públicos alçados por via legislativa a cargo de maior responsabilidade do que aquele para o qual foram eles aprovados em concurso. Não se verificou, no caso, um gradual processo de sincretismo entre os cargos, senão que uma abrupta reformulação da condição dos comissários de polícia, que em menos de três anos deixaram de ter suas características originais para passar a um cargo organizado em carreira.

Ainda no campo dos concursos públicos, foi editada a Súmula Vinculante 44, refletindo a jurisprudência convergente em torno da tese de que «só por lei se pode sujeitar a exame psicotécnico a habilitação de candidato a cargo público». O entendimento foi sumulado, diante dos repetidos casos de imposição de testes psicotécnicos, sem que lei o houvesse admitido. Esses 
testes, cuja análise e interpretação suscita problemas de subjetivismo, deve-se submeter a juízo de necessidade aferida pelo Poder Legislativo.

Outro assunto debatido foi o direito de o aprovado em concurso público exigir que seja nomeado. $\mathrm{O}$ concurso é aberto, porque a Administração necessita de servidores. Além disso, o concurso possui prazo de validade, que a Administração indica no edital do certame. Se a Administração aproveita os melhores aprovados, mas não todos, poderá, ao término do prazo de validade do certame, abrir novo concurso para prover os cargos ainda vagos?

A indagação se reveste de importância social, uma vez que o ingresso em carreiras públicas, especialmente quando a crise na economia deprime o número de empregos na iniciativa privada, tem-se tornado elemento crucial para o acesso à classe média e para que os que nela se situam, nela permaneçam. A preparação para concursos mobiliza milhões de brasileiros, que se dedicam, às vezes, por anos, afastados de outras atividades produtivas, para obter êxito nessas disputas, em que a disparidade entre interessados e cargos a serem providos não raro atinge quocientes elevadíssimos, na casa das várias centenas, quando não dos milhares.

A resposta que o STF forneceu à indagação está expressa no RE 837.311RG, julgado no Plenário em 9.12.2015, que expõe com clareza em que coordenadas o problema se encontra e a solução a ser seguida nas disputas judiciais a respeito. $\mathrm{O}$ acórdão começa apontando a importância do concurso público na ordem constitucional brasileira e as consequências que devem ser acordadas ao candidato que acreditou na seriedade do certame e nele obteve êxito:

O postulado do concurso público traduz-se na necessidade essencial de o Estado conferir efetividade a diversos princípios constitucionais, corolários do merit system, dentre eles o de que todos são iguais perante a lei, sem distinção de qualquer natureza (CRFB/88, art. 5\%, caput). O edital do concurso com número específico de vagas, uma vez publicado, faz exsurgir um dever de nomeação para a própria Administração e um direito à nomeação titularizado pelo candidato aprovado dentro desse número de vagas. Precedente do Plenário: RE 598.099 — RG, Relator Min. Gilmar Mendes, Tribunal Pleno, DJe 03-10-2011.

O Tribunal, então, mesmo reconhecendo que a aprovação em concurso gera direitos para o concursando, explicitou que daí não decorre perda de todo espaço de discricionariedade para a Administração:

O Poder Judiciário não deve atuar como "Administrador Positivo», de modo a aniquilar o espaço decisório de titularidade do administrador para decidir sobre o que é melhor para a Administração: se a convocação dos últimos colocados de concurso público na validade ou a dos primeiros aprovados em um novo concurso. Essa escolha é legítima e, ressalvadas as hipóteses de abuso, não encontra obstáculo em 
qualquer preceito constitucional. Consectariamente, é cediço que a Administração Pública possui discricionariedade para, observadas as normas constitucionais, prover as vagas da maneira que melhor convier para o interesse da coletividade, como verbi gratia, ocorre quando, em função de razões orçamentárias, os cargos vagos só possam ser providos em um futuro distante, ou, até mesmo, que sejam extintos, na hipótese de restar caracterizado que não mais serão necessários.

Fixadas essas premissas, o tema em debate recebeu contornos mais definidos. $\mathrm{O}$ caso em apreço envolvia pretensão de quem, embora aprovado no concurso, fora classificado em posição que excedia o número de vagas abertas pelo edital do concurso. A questão se pôs em saber se, mesmo assim, ante a abertura de novas vagas durante a validade do concurso que prestou, a Administração estava compelida a recrutá-lo, antes de abrir novo certame, independentemente de o prazo de validade do concurso do interessado ter-se, ou não, exaurido. Eis a resposta da Corte:

Nesse contexto, a Administração Pública detém a prerrogativa de realizar a escolha entre a prorrogação de um concurso público que esteja na validade ou a realização de novo certame. (...) O surgimento de novas vagas ou a abertura de novo concurso para o mesmo cargo, durante o prazo de validade do certame anterior, não gera automaticamente o direito à nomeação dos candidatos aprovados fora das vagas previstas no edital, ressalvadas as hipóteses de preterição arbitrária e imotivada por parte da administração, caracterizadas por comportamento tácito ou expresso do Poder Público capaz de revelar a inequívoca necessidade de nomeação do aprovado durante o período de validade do certame, a ser demonstrada de forma cabal pelo candidato.

Repare-se que somente nestas hipóteses mais extremadas a discricionariedade da Administração desaparece. O direito à nomeação, portanto, estará caracterizado:

i) Quando a aprovação ocorrer dentro do número de vagas do edital (RE 598.099);

ii) Quando houver preterição na nomeação por não observância da ordem de classificação (Súmula 15 do STF); iii) Quando surgirem novas vagas, ou for aberto novo concurso durante a validade do certame anterior, e ocorrer a preterição de candidatos aprovados fora das vagas de forma arbitrária e imotivada por parte da administração nos termos acima.

Essas noções foram avançadas também em voto vogal do MinistroTeori Zawaski, no RE 724.347, DJe 12.5.2015, que resumiu a requintada jurisprudência em torno dos percalços administrativos que os concursos podem ter que atravessar. Referindo-se ao art. 37, IV, da Constituição ( $D$ Durante o pra- 
zo improrrogável previsto no edital de convocação, aquele aprovado em concurso público de provas ou de provas e títulos será convocado com prioridade sobre os novos concursados para assumir cargo ou emprego, na carreira»), o Ministro repisou o que se tem assentado sobre o significado da expressão "com prioridade» inscrita na norma:

A Corte já decidiu, por exemplo, que (a) a situação de preterição causada em decorrência de decisão judicial não gera direito de nomeação (RMS 23.511, 1a T., Min. Octavio Gallotti, DJ de 10/11/00; AI 373054 AgR, 1a T., Mina Ellen Gracie, DJ de 27/9/02; RE 437403, 2a T., Rel. Min. Gilmar Mendes, DJ de 5/5/06); (b) os candidatos aprovados dentro do número de vagas possuem direito subjetivo à nomeação durante o prazo de validade do concurso, salvo se devidamente comprovada a superveniência de situação imprevisível, grave e incontornável que torne materialmente impossível o cumprimento do dever de investir os aprovados nos cargos (RE 598.099, Pleno, Rel. Min. Gilmar Mendes, DJe de 3/10/11); e (c) a contratação de funcionários, em regime precário, durante o período de validade do concurso implica preterição dos candidatos aprovados para exercício das mesmas funçôes, ainda que o tenham sido fora do número de vagas oferecidas em edital (ARE 692368 AgR, 2a T., Rela. Mina. Cármen Lúcia, DJe de 4/10/12; ARE 649046 AgR, 1a T. Rel. Min. Luiz Fux, DJe de 13/9/12; e RMS 29915 AgR, Rel. Min. Dias Toffoli, DJe de 26/9/12).

Este é, hoje, o tônus normativo da noção constitucional de prioridade que milita em favor da contratação dos aprovados em concursos públicos. Pode-se dizer que ela impōe uma série de deveres sucessivos à Administração, dentre os quais os de (a) convocar os aprovados dentro do número de vagas previsto em edital; (b) motivar apropriadamente eventual não convocação; (c) não preterir a ordem de classificação estabelecida após a correção das provas, salvo se por imposição de determinação judicial; e (d) não empregar expedientes de contratação precários durante o prazo de validade de concursos para a mesma função. Ocorrendo o descumprimento de quaisquer desses deveres implícitos, terão os aprovados uma pretensão legítima a ser exercida contra a Administração por meio de ação judicial. E se, durante o processamento da demanda, não restarem provados fatos extintivos, impeditivos ou modificativos do direito de prioridade, seguir-se-á a nomeação como desfecho natural.

No precedente, estava em exame saber se era indenizável a demora na posse em cargo público, que havia sido determinada por decisão judicial. O autor da demanda pretendia receber a remuneração do cargo desde que obteve a ordem judicial, mesmo durante o período, portanto, em que ainda não estava trabalhando. Houve debates extensos no Plenário. Lembrou-se que as ordens a esse respeito, na maioria dos casos, se referem a atos administrativos anteriores ao momento da nomeação, muitas vezes aludindo a controvérsias envolvendo etapas do concurso público. Nesses casos, habitualmente, o direito 
ao cargo somente se aperfeiçoa ao término do processo cognitivo, no instante, portanto, da execução. A demora, aí, não seria indenizável, por decorrer do próprio sistema processual. A situação ganharia contornos diversos, quando a ordem se direcionasse diretamente à nomeação, obstada por motivos espúrios. Foi argumentado, igualmente, que a jurisprudência da Corte orientava-se, até ali, em proporção majoritária, por não admitir que a indenização corresponda à remuneração que o autor receberia se estivesse no desempenho do cargo. Em uma tal pretensão haveria o obstáculo que o princípio da moralidade, do republicanismo e do veto ao enriquecimento indevido erguem a que se receba por serviço que não foi prestado. Afinal, registrou-se a tese esta ser seguida pelos demais órgãos judiciários do País: «Na hipótese de posse em cargo público determinada por decisão judicial, o servidor não faz jus a indenização, sob fundamento de que deveria ter sido investido em momento anterior, salvo situação de arbitrariedade flagrante».

Questão outra, conexa a essa, foi apreciada no RMS 31.538, julgado na Primeira Turma em 17.11.2015. Novamente aqui, cuidava-se de estipular que efeito deveria ser reservado a decisão judicial que determinava a posse em cargo público. A situação peculiarizava-se, entretanto, porque a ordem judicial era de natureza liminar, passível de ser superada ao longo do processo de conhecimento, embora houvesse sido cumprida imediatamente. Passados vários anos, já havendo o beneficiado pela decisão desempenhado longamente as atribuiçôes do cargo, a decisão liminar vem a ser derrubada, julgando-se improcedente o pedido do autor. A consequência desse desfecho retirou a base para que o autor permanecesse no cargo. $\mathrm{O}$ servidor argumentou que o seu afastamento contrariaria o princípio da proteção da confiança, já que uma fora consolidada uma situação de fato, cujo desprezo frustraria «legítimas expectativas".

$\mathrm{O}$ argumento foi rejeitado pela Corte. Anotou-se que o autor não poderia nutrir legitimamente expectativa de que uma decisão, por sua natureza precária, asseguraria a sua permanência definitiva no serviço público. Afinal, frisou-se que "o indeferimento de ordem, em mandado de segurança, revogada a liminar, implica condição resolutiva da nomeação, não cabendo potencializar fato que foi consumado sob o ângulo precário e efêmero».

O prestígio do princípio do concurso público na jurisprudência do Tribunal pode ser medido, também, pela proibição que a Corte inseriu em verbete de sua Súmula Vinculante de que parente de autoridade pública seja nomeado para cargo sob a sua subordinação.

$\mathrm{Na}$ ADI 524, julgada em 20.5.2015, especificou-se que essa vedação incide «sobre cargos de provimento em comissão, função gratificada e cargos e direção e assessoramento", que são hipóteses em que se admite o ingresso em cargo público sem concurso, sempre, porém, em caráter precário e tem- 
porário. A limitação não alcança os servidores admitidos mediante concurso público, ocupantes de cargo de provimento efetivo.

\section{APLICAÇÃO DE PRINCÍPIOS REITORES DE UMA ADMINISTRAÇÃO DEMOCRÁTICA}

No item acima, expôs-se caso em que o Supremo Tribunal, por maioria, entendeu que não era de se aplicar o princípio da proteção da confiança. A invocação desse princípio, associado ao da segurança jurídica, tem-se avolumado tanto em petições dirigidas ao STF como em suas deliberações, provando ser um tópico argumentativo aberto à criatividade na busca da justiça em casos especiais.

No MS 31.477 AgR, a Primeira Turma, em 3.3.2015, estabeleceu que o postulado da segurança jurídica veda que o Tribunal de Contas da União, quando assume um novo e mais restritivo entendimento sobre pressupostos para aposentadoria, não pode aplicá-lo a casos já apreciados pela Corte antes da mudança de inteligência.

No RE 730.462-RG, julgado em 28.5.2015, o Plenário esclareceu que a coisa julgada, que também exprime garantia voltada ao propósito da segurança jurídica, não perde a sua eficácia pela razão isolada de a sentença haver buscado fundamento em lei que o STF veio, mais tarde, declarar inconstitucional em controle abstrato.

Nesse precedente, foram fixadas algumas balizas de raciocínio, a partir de uma distinção doutrinária. $\mathrm{O}$ controle abstrato, quando dele resulta juízo de inconstitucionalidade de lei, como regra, atinge a validade da lei, desde o momento em que o diploma foi editado, já que a decisão apenas declara a realidade preexistente da ofensa à Constituição. O Tribunal situou essa consequência como própria do plano normativo. A decisão do STF produz o efeito de excluir do ordenamento jurídico a norma inconstitucional.

No plano dos fatos, entretanto, há consequência diferente, que o relator, Ministro Teori Zawaski, chamou de «eficácia executiva», em oposição à primeira, denominada de "eficácia normativa». Essa eficácia executiva decorre da decisão do Tribunal e não da inconstitucionalidade em si da norma. A eficácia executiva consiste na imposição de que atos administrativos e judiciais posteriores ao julgado sigam o entendimento assentado sobre a validade da lei, examinada no controle abstrato, sob pena de se verem cassados, por meio de reclamação, pelo STF. Tendo em vista o disposto no art. 28 da Lei no 9.868/99, esse efeito vinculante se dá a partir da publicação da parte dispositiva do acórdão no Diário Oficial. A eficácia executiva não atinge, portanto, os atos que foram praticados antes da publicação do pronunciamento do STF. Esses atos 
pretéritos devem ser atacados pelos meios disponíveis no ordenamento jurídico. Se não houver instituto que permita impugná-los, permaneceram eficazes. Assim, se se trata de uma sentença judicial transitada em julgado antes da decisão do STF no controle abstrato, ela deverá ser objeto de ação rescisória, se ainda houver prazo para tanto. No julgado, salientou-se que o novo Código de Processo Civil, que passou a vigorar no início de 2015, fixa o prazo bienal da ação rescisória, adotando, porém, nesses casos, a própria decisão do STF como termo de início, e, não, como habitual em outras hipóteses, a data do trânsito em julgado da sentença rescindenda.

Numa hipótese, contudo, a eficácia executiva atingirá, em parte, a sentença produzida anteriormente. Isso ocorrerá nas hipóteses de sentenças que geram obrigações de trato sucessivo. Sendo esse o caso, a sentença deixará de produzir efeitos a partir da deliberação do STF, sem a necessidade, decerto, de medida judicial que o estabeleça ${ }^{3}$.

3 Esta é a ementa do acórdão:

CONSTITUCIONAL E PROCESSUAL CIVIL. DECLARAÇÃO DE INCONSTITUCIONALIDADE DE PRECEITO NORMATIVO PELO SUPREMO TRIBUNAL FEDERAL. EFICÁCIA NORMATIVA E EFICÁCIA EXECUTIVA DA DECISÃO: DISTINÇÕES. INEXISTÊNCIA DE EFEITOS AUTOMÁTICOS SOBRE AS SENTENÇAS JUDICIAIS ANTERIORMENTE PROFERIDAS EM SENTIDO CONTRÁRIO. INDISPENSABILIDADE DE INTERPOSIÇÃO DE RECURSO OU PROPOSITURA DE AÇÃO RESCISÓRIA PARA SUA REFORMA OU DESFAZIMENTO. 1. A sentença do Supremo Tribunal Federal que afirma a constitucionalidade ou a inconstitucionalidade de preceito normativo gera, no plano do ordenamento jurídico, a consequência (= eficácia normativa) de manter ou excluir a referida norma do sistema de direito. 2. Dessa sentença decorre também o efeito vinculante, consistente em atribuir ao julgado uma qualificada força impositiva e obrigatória em relação a supervenientes atos administrativos ou judiciais (= eficácia executiva ou instrumental), que, para viabilizar-se, tem como instrumento próprio, embora não único, o da reclamação prevista no art. 102, I, «l», da Carta Constitucional. 3. A eficácia executiva, por decorrer da sentença (e não da vigência da norma examinada), tem como termo inicial a data da publicação do acórdão do Supremo no Diário Oficial (art. 28 da Lei 9.868/1999). É, consequentemente, eficácia que atinge atos administrativos e decisões judiciais supervenientes a essa publicação, não os pretéritos, ainda que formados com suporte em norma posteriormente declarada inconstitucional. 4. Afirma-se, portanto, como tese de repercussão geral que a decisão do Supremo Tribunal Federal declarando a constitucionalidade ou a inconstitucionalidade de preceito normativo não produz a automática reforma ou rescisão das sentenças anteriores que tenham adotado entendimento diferente; para que tal ocorra, será indispensável a interposição do recurso próprio ou, se for o caso, a propositura da ação rescisória própria, nos termos do art. 485, V, do CPC, observado o respectivo 


\section{O STF E O DIREITO POLÍTICO}

No campo dos direitos políticos, o STF tomou decisão de grande impacto e geradora de não menor polêmica. Em 17.9.2015, a Corte deliberou, na ADI 4650, que as pessoas jurídicas não podem contribuir financeiramente para as campanhas eleitorais, fulminando lei ordinária que o autorizava. $\mathrm{O}$ Tribunal, dividido, entendeu que a Constituição repele a desigualdade — que prejudicaria o cidadão comum, em comparação com a empresa endinheirada - na participação política eleitoral.

A corrente majoritária invocou o art. $14, \$ 9^{\circ}$, da Constituição, que confia à lei a tarefa de assegurar a "legitimidade das eleições contra a influência do poder econômico». A corrente minoritária sustentou, sem êxito, que a Constituição não impede a contribuição econômica das empresas e que o abuso é de ser obviado pela instituição de limites a essas doaçôes ${ }^{4}$.

Em outro caso, também envolvendo campanhas eleitorais, o Tribunal concedeu medida liminar em ação direta de inconstitucionalidade para suspender a aplicação de dispositivo de lei que admitia a doação anônima de particulares para candidatos a cargos políticos (ADI 5394 MC/DF, julgada

prazo decadencial (CPC, art. 495). Ressalva-se desse entendimento, quanto à indispensabilidade da ação rescisória, a questão relacionada à execução de efeitos futuros da sentença proferida em caso concreto sobre relações jurídicas de trato continuado. 5. No caso, mais de dois anos se passaram entre o trânsito em julgado da sentença no caso concreto reconhecendo, incidentalmente, a constitucionalidade do artigo $9^{\circ}$ da Medida Provisória 2.164-41 (que acrescentou o artigo 29-C na Lei 8.036/90) e a superveniente decisão do STF que, em controle concentrado, declarou a inconstitucionalidade daquele preceito normativo, a significar, portanto, que aquela sentença é insuscetível de rescisão. 6. Recurso extraordinário a que se nega provimento.

4 Coligem-se abaixo alguns trechos da decisão que expressam o pensamento da maioria formada:

A Constituição da República, a despeito de não ter estabelecido um modelo normativo pré-pronto e cerrado de financiamento de campanhas, forneceu uma moldura que traça limites à discricionariedade legislativa, com a positivação de normas fundamentais (e.g., princípio democrático, o pluralismo político ou a isonomia política), que norteiam o processo político, e que, desse modo, reduzem, em alguma extensão, o espaço de liberdade do legislador ordinário na elaboração de critérios para as doações e contribuiçôes a candidatos e partidos políticos.

A formulação de um modelo constitucionalmente adequado de financiamento de campanhas impõe um pronunciamento da Corte destinado a abrir os canais de diálogo com os demais atores políticos (Poder Legislativo, Executivo e entidades da sociedade civil). 
em 12.11.2015). Para o Tribunal, a norma turvava a necessária transparência das contas eleitorais, obstando a Justiça eleitoral de «fiscalizar se o desenvolvimento da atividade político-partidária realmente assegura a autenticidade do sistema representativo". Além disso, a regra embaraçava a verificação da licitude das fontes financeiras da campanha, bem como impedia o eleitor de acompanhar que forças apoiam o candidato que se propóe ao seu voto.

Há alguns anos, o STF decidiu que o parlamentar que abandona o partido político pelo qual se elegeu, para se filiar a outro, sujeita-se a perder o mandato. Analisando as características do sistema de representação proporcional, em que se ressalta como fator decisivo para a distribuição das cadeiras do Legislativo o quociente eleitoral obtido pela agremiação partidária, o Supremo Tribunal assentou que o mandato dos eleitos segundo o sistema proporcional pertencia antes ao partido do que ao próprio parlamentar, daí resultando a perda do mandato do que era infiel ao partido que o elegeu.

Depois dessa decisão, o Tribunal Superior Eleitoral editou norma aplicando essa mesma orientação aos casos de políticos eleitos pelo sistema majoritário. Por esse sistema, o candidato mais votado conquista o lugar disputado. Esse é o sistema que adotado no Brasil para a eleição de Senadores e dos Chefes do Executivo da União, dos Estado-membro e do Distrito Federal, bem como dos Municípios.

Dadas as características do sistema majoritário, o Tribunal, analisando a ADI 5081, em 27.5.2015, entendeu que, aqui, o voto não se direciona primordialmente ao partido, mas, sim, prioritariamente ao candidato, não se aplicando o raciocínio construído sobre a fidelidade ao partido exigida dos eleitos pelo sistema de voto proporcional. A resolução do Tribunal Superior Eleitoral foi declarada incompatível com a sistemática constitucional regente das eleições majoritárias.

\section{LIBERDADE DE EXPRESSÃO, DIREITO A INFORMAÇÃO E PRIVACIDADE}

No domínio do clássico entrechoque dos direitos fundamentais à informação e expressão com pretensões de privacidade, em importantes julgamentos, a balança do Tribunal pendeu favoravelmente aos dois primeiros.

No RE 652.777-RG, o STF julgou, em 23.4.2015, que a invocação da privacidade e de motivos de segurança pessoal dos servidores públicos não esbatiam a prioridade da transparência que os atos da Administração Pública devem conter para o controle da cidadania num contexto republicano. Decidiu-se, por isso, que é legítima a publicação em portais da Internet dos órgãos 
da Administração do nome dos servidores, com o cargo que ocupa, seguido da exata remuneração recebida dos cofres públicos.

Já no MS 33.340, julgado em 26.5.2015, assentou-se que o Tribunal de Contas da União, órgão auxiliar do Congresso Nacional no controle do emprego de valores públicos federais, pode exigir que banco estatal de investimento forneça informaçōes por este colhidas ao conceder empréstimo para entidade privada. A Primeira Turma proclamou que «o sigilo de informaçóes necessárias para a preservação da intimidade é relativizado quando se está diante do interesse da sociedade de se conhecer o destino dos recursos públicos». A invocação do direito ao sigilo foi repudiada, com a afirmação de que «quem contrata com o poder público não pode ter segredos, especialmente se a revelação for necessária para o controle da legitimidade do emprego dos recursos públicos. É que a contratação pública não pode ser feita em esconderijos envernizados por um arcabouço jurídico capaz de impedir o controle social quanto ao emprego das verbas públicas». Foi ratificada a jurisprudência de que, em princípio, o TCU somente pode quebrar sigilo bancário por meio de ordem do Judiciário, mas foi asseverada a «inoponibilidade de sigilo bancário e empresarial ao TCU quando se está diante de operações fundadas em recursos de origem pública [dado o] dever de atuação transparente dos administradores públicos em um Estado Democrático de Direito».

Por último, foi julgada a $\mathrm{ADI} 4.815$, em 10.6.2015, que atacava dispositivos do Código Civil de $2002^{5}$, que vinham sendo lidos de forma a impedir que se publicassem biografias com as quais o retratado não concordasse. A Corte valeu-se da técnica da interpretação conforme a Constituição, para declarar a inconstitucionalidade sem redução de texto da compreensão que subordinava a liberdade de expressão de criação artística e a produção científica à autorização da pessoa biografada (ou de seus familiares) em obras literárias ou audiovisuais, quer a pessoa retratada aparecesse como foco central da obra, quer como coadjuvante.

5 Os dispositivos do Código Civil relevantes têm esta redação:

Art. 20. Salvo se autorizadas, ou se necessárias à administração da justiça ou à manutenção da ordem pública, a divulgação de escritos, a transmissão da palavra, ou a publicação, a exposição ou a utilização da imagem de uma pessoa poderão ser proibidas, a seu requerimento e sem prejuízo da indenização que couber, se lhe atingirem a honra, a boa fama ou a respeitabilidade, ou se se destinarem a fins comerciais.

Parágrafo único. Em se tratando de morto ou de ausente, são partes legítimas para requerer essa proteção o cônjuge, os ascendentes ou os descendentes.

Art. 21. A vida privada da pessoa natural é inviolável, e o juiz, a requerimento do interessado, adotará as providências necessárias para impedir ou fazer cessar ato contrário a esta norma. 
O Tribunal concordou em que:

A Constituição do Brasil proíbe qualquer censura. O exercício do direito à liberdade de expressão não pode ser cerceada pelo Estado ou por particular. O direito de informação, constitucionalmente garantido, contém a liberdade de informar, de se informar e de ser informado. O primeiro refere-se à formação da opinião pública, considerado cada qual dos cidadãos que pode receber livremente dados sobre assuntos de interesse da coletividade e sobre as pessoas cujas açôes, público-estatais ou público-sociais, interferem em sua esfera do acervo do direito de saber, de aprender sobre temas relacionados a suas legítimas cogitaçōes. Biografia é história. A vida não se desenvolve apenas a partir da soleira da porta de casa. Autorização prévia para biografia constitui censura prévia particular. $\mathrm{O}$ recolhimento de obras é censura judicial, a substituir a administrativa. O risco é próprio do viver. Erros corrigem-se segundo o direito, não se coartando liberdades conquistadas. A reparação de danos e o direito de resposta devem ser exercidos nos termos da lei.

\section{DIREITOS SOCIAIS E IGUALDADE}

Em dois episódios, a jurisprudência analisou direitos sociais confrontados com invocação da isonomia.

No RE 658.312-RG, DJe 10.12.2015, o Tribunal garantiu não ser inválido que o legislador dispense tratamento diferenciado e mais propício à mulher, com relação ao homem, dentro de determinados parâmetros. No caso, o Supremo Tribunal se defrontou com crítica à não-extensão aos homens de norma trabalhista asseguradora de um intervalo de descanso de 15 minutos entre a jornada normal de trabalho e o início das horas extras a serem prestadas. O Tribunal não apenas reiterou que a garantia da igualdade não é absoluta, como também justificou o tratamento diferenciado, excluindo a hipótese de privilégio censurável, referindo-se à menor resistência física da mulher e a um componente sócio-cultural brasileiro, que se tem denominado de «dupla jornada», para expressar a circunstância de a mulher não apenas enfrentar o trabalho fora de casa, como, também, sobre ela pesar a parte mais exigente das tarefas do $\operatorname{lar}^{6}$.

6 Consta da decisão esse resumo de argumentos:

O princípio da igualdade não é absoluto, sendo mister a verificação da correlação lógica entre a situação de discriminação apresentada e a razão do tratamento desigual. A Constituição Federal de 1988 utilizou-se de alguns critérios para um tratamento diferenciado entre homens e mulheres: i) em primeiro lugar, levou em consideração a histórica exclusão da mulher do mercado regular de trabalho e impôs ao Estado a 
Em um outro julgado (RE 581488-RG, de 3.12.2015), o Tribunal apreciou a questão de saber se o paciente de hospital da rede pública poderia, contra regra específica disposta em portaria do Ministério da Saúde, obter internação em melhores condições de conforto e tratamento mais personalizado se pagasse pelas vantagens.

A compreensão do problema será facilitada para o leitor estrangeiro com a notícia de que, no Brasil, vigora um sistema de saúde vocacionado a atender a todos os brasileiros e de modo gratuito. Ao lado dessa rede de saúde pública, referida como SUS, convive a medicina particular, a que parte significativa da população não tem acesso, por falta de meios econômicos. O Tribunal, no caso, não avalizou a pretensão de que se inserisse uma diferenciação entre pacientes da rede pública, ditada, não por imperativos médicos, mas por disparidade de condiçôes financeiras. A Corte entendeu válida a norma atacada, que impõe a igualdade que o sistema de saúde pública pressupõe. Na decisão constam estas palavras:

O procedimento da "diferença de classes», tal qual o atendimento médico diferenciado, quando praticados no âmbito da rede pública, não apenas subverte a lógica que rege o sistema de seguridade social brasileiro, como também afronta o acesso equânime e universal às ações e serviços para promoção, proteção e recuperação da saúde, violando, ainda, os princípios da igualdade e da dignidade da pessoa humana.

\section{FEDERAÇÃO}

Em todos os anos, o Supremo Tribunal Federal enfrenta questôes de definição do funcionamento do federalismo no Brasil. A tendência histórica tem sido a de reforçar um visão centrípeta dessa forma de Estado, favorecendo uma mais intensa uniformidade na conformação da vida institucional nas esferas da União, estadual e municipal.

obrigação de implantar políticas públicas, administrativas e/ou legislativas de natureza protetora no âmbito do direito do trabalho; ii) considerou existir um componente orgânico a justificar o tratamento diferenciado, em virtude da menor resistência física da mulher; e iii) observou um componente social, pelo fato de ser comum o acúmulo pela mulher de atividades no lar e no ambiente de trabalho - o que é uma realidade e, portanto, deve ser levado em consideração na interpretação da norma. Esses parâmetros constitucionais são legitimadores de um tratamento diferenciado desde que esse sirva, como na hipótese, para ampliar os direitos fundamentais sociais e que se observe a proporcionalidade na compensação das diferenças. 
O modelo de processo legislativo federal, sobretudo, tido como de reprodução obrigatória, há muito que rende uma considerável quantidade de polêmicas resolvidas pelo Supremo Tribunal com declarações de inconstitucionalidade de diplomas locais. No campo das competências concorrentes, em 2015, a Corte teve o ensejo de reiterar que se o Município pode legislar para complementar e adaptar a legislação estadual e federal, por outro lado não lhe é dado dispor em sentido que frustre o objetivo buscado nessa outras esferas legislativas.

Com fundamento nessa premissa, em 5.3.2015, sob a sistemática da repercussão geral, julgou-se o RE 586.224, em que se declarou a inconstitucionalidade de lei municipal que dispunha sobre queimadas de terras de cultivo da cana-de-açúcar. Foi reconhecida a legitimidade do Município para legislar sobre meio-ambiente naquilo que diga com o seu interesse peculiar, advertindo-se, todavia, que, havendo conflito do diploma municipal com o estadual, prevalece este, por abarcar mais amplo interesse. No caso, prevaleceu o diploma estadual que prevê a eliminação gradual da queima da cana-de-açúcar, sobre o do Município, que a proibia desde logo.

Quando se cuida de competência concorrente da União e dos Estadosmembros para legislar sobre um mesmo setor da vida das relaçôes, cabe à União editar os princípios gerais, as normas-quadro, enquanto ao Estadomembro é dado suprir lacunas ou pormenorizar as regras federais, sem desrespeitar as normas gerais dispostas pelo Congresso Nacional. Por vezes, essa distinção suscita polêmicas.

$\mathrm{Na}$ ADI 4060, de 25.2.2015, o Tribunal considerou legítima a lei estadual que, a propósito do tema da educação e ensino, inserido no condomínio legislativo do Estado-membro com a União, fixou um número máximo de alunos por sala de aula. Não houve dificuldade, aí, de perceber que:

O limite máximo de alunos em sala de aula não ostenta natureza de norma geral, uma vez que dependente das circunstâncias peculiares a cada ente da federação, tais como o número de escola colocadas à disposição da comunidade, a oferta de vagas para o ensino, o quantitativo de crianças em idade escolar para o nível fundamental e médio, o número de professores em oferta na região, além de aspectos ligados ao desenvolvimento tecnológico nas áreas de educação e ensino.

Ainda sobre competência legislativa do Estado-membro, na ADI 2314, de 17.6.2015, o Plenário se afastou explicitamente de precedentes anteriores, para decidir que, se o tema é admitido à competência legislativa das unidades federadas, a Constituição estadual pode determinar o tipo de lei (se ordinária, que exige quórum de maioria simples, ou complementar, que cobra maioria absoluta para a aprovação) que deverá instrumentar o regramento, indepen- 
dentemente da forma que a Constituição Federal prevê para tratar do tema no âmbito federal. Foi enfatizado que, dessa maneira, prestigiava-se a autonomia dos Estados.

\section{CONCLUSÃO}

Ao longo de 2015, o quadro popular de descontentamento e desgosto com a gestão da coisa pública —em especial quanto a estarrecedoras descobertas de bilionários casos de corrupção e quanto à sensação de descontrole financeiro-econômico no país- gerou manifestações públicas bastante significativas e suscitou cobranças por mais eficiência na repressão e prevenção de abusos. O Supremo Tribunal foi provocado a intervir nesse ambiente marcado pela generalizada convicção de serem imprescindíveis mudanças na arquitetura jurídica e política da nação. Não se pode recusar à Corte o bom sucesso no requintado trabalho a que se devotou de equilibrar imperativos dos direitos individuais e políticos básicos com as aspirações de reestruturação moralizadora do setor público. A jurisprudência no ano de 2015 demonstra essa realidade e revela também que o Tribunal não ficou tomado exclusivamente pelos grandes dramas que dominaram o país, aplicando-se também na habitual tarefa de assegurar a melhor aplicação da Carta da República nos mais variados setores da vida jurídica nacional. 